\title{
ENGLAND: DID THE DECISION OF THE SUPREME COURT IN THE CASE OF JONES V KERNOTT CLARIFY THE LAW IN RELATION TO TRUSTS OF THE FAMILY HOME?
}

\author{
Barttomiej Orawiec*
}

\begin{abstract}
This dissertation will focus on common intention constructive trusts in relation to shared ownership of the family home predominantly in relation to unmarried couples. These trusts are particularly important because as opposed to married couples where the court may determine a couple's financial and property issues upon divorce using the provisions of the Matrimonial Causes Act 1973, the position of unmarried couples is not covered by any legislation and so judges need to refer back to case law and property law in order to establish the equitable ownership of property.
\end{abstract}

Key words: constructive trusts, family home, cohabitation, equitable ownership, unmarried couples

In Paragon Finance plc v DB Thakerar \& $C o^{1}$, Millet LJ defined a constructive trust as a "trust which arises by operation of law whenever the circumstances are such that it would be unconscionable for the owner of property

* Currently a PhD Candidate at the Jagiellonian University, Faculty of Law and Administration, Economic Policy. Also graduated with LLB Law (Hons) from University of Northampton and was awarded 'Certificate of Commendation from the University of Northampton Law Board of Study for the Outstanding Academic Achievement' and won 'Shoosmiths prize for Outstanding Contribution to Corporate Responsibility 2014'. He also completed LLM with LPC (Legal Practice Course) at the University of Law, London.

${ }^{1}$ [1999] 1 All ER 400 
(usually but not necessarily the legal estate) to assert his own beneficial interest in the property and deny the beneficial interest of another" ${ }^{2}$. The boundaries of the definition of a constructive trust "have been left perhaps deliberately vague, so as not to restrict the court by technicalities in deciding, what the justice of a particular case may demand"3. Although there are many different types of constructive trusts, the following categories are the most significant: a breach of fiduciary duty, theft, receipt of property by mistake, fraud, and assistance in a breach of a trust $\mathrm{t}^{4}$.

This dissertation will focus on common intention constructive trusts in relation to shared ownership of the family home predominantly in relation to unmarried couples. These trusts are particularly important because as opposed to married couples where the court may determine a couple's financial and property issues upon divorce using the provisions of the Matrimonial Causes Act 1973, the position of unmarried couples is not covered by any legislation and so judges need to refer back to case law and property law in order to establish the equitable ownership of property. Following Lord Reid's judgment in Pettitt $v$ Pettitt ${ }^{5}$ and latter in s 199 of the Equality Act 2010 (not yet in force), the 'presumption of advancement' ${ }^{\prime}$ does not apply to modern cases involving family home trusts ${ }^{7}$.

There are many social issues surrounding common intention constructive trusts in relation to cohabitation of unmarried couples. In the recent years, it has become socially acceptable for unmarried couples (heterosexual and homosexual) to live together either for convenience or out of sexual desire with no intention of forming a permanent relationship. People may simply share accommodation which they have bought in joint names. It is no longer the case that men make more financial contributions towards property than women. However, in many cases women who have decided

2 Ibid.

3 LJ Edmund Davies in Carl Zeiss Stiftung v Herbert Smith \& Co [1969] 2 Ch 276 at 300 .

${ }^{4}$ A. Hudson, Equity and Trusts, 7th ed., Routledge, 2012, p. 549-553.

5 [1970] AC 777.

6 Presumption of advancement in cases involving husband and wife means that where a husband made a transfer of property to his wife, the presumption was that the husband intended to make an outright gift of such property - Tinker v Tinker [1970] P 136.

7 A. Hudson, Equity and Trusts, 7th ed., Routledge, 2012, p. $521-526$. 
to stay home and take care of children have been in an economically disadvantageous position because, while caring for the offspring, they were unable to make financial contributions towards the property ${ }^{8}$. People who trust each other tend not to make formal agreements and this can later cause difficulties in establishing the equitable ownership of the property. Also, people's views may change over time and they may decide to separate, move out or leave their cohabitee. They may also go through many life experiences which they often have not predicted such as redundancy, poverty, illness, accident, sudden enrichment, children conceived by accident, or bad luck ${ }^{9}$. No matter what the situation is, parties demonstrate a variety of intentions while cohabiting together and some of them can give rise to establishing an equitable interest in property.

The most straightforward situation for courts to decide is where there has been an 'express trust' ${ }^{10}$ declared that allocates the entire equitable interest in the property between the parties ${ }^{11}$. In Goodman $v$ Gallant ${ }^{12}$ there was an express trust declared which provided that the property was to be held on trust for the parties as joint tenants. It was held that although there were different financial contributions made by the parties towards the estate, the appellant took only half of the interest in the property as the "declaration contained in the document [spoke] for itself" 13. However if there is no express trust declared, the courts will have to look at the parties' intentions to decide who ought to acquire rights in the home in order to prevent mortgagees from repossessing it, to decide who should continue to live in it, how to divide proceeds of sale, or to prevent third parties from purchasing it.

The development of the case law in relation to common intention constructive trusts started in 1970s with cases such as Pettitt $v$ Pettitt ${ }^{14}$ where the House of Lords "[began] the process of staking out the modern code of

8 Ibid, at p. 702-704.

9 Ibid, pp. 702-704.

10 The declaration of an express trust must satisfy s53(1)(b) of the Law of Property Act 1925.

11 A. Hudson, Equity and Trusts, 7th ed., Routledge, 2012, p. 708-709.

12 [1986] FLR 513.

13 Slade LJ in Goodman v Gallant [1986] Fam. 106 at 111.

14 [1970] AC 777. 
rules to deal with the allocation of equitable interests in the family home... "15. However, it was Lord Diplock in Gissing $v$ Gissing ${ }^{16}$ who first introduced the concept of 'common intention', which provided judges with greater discretion in making decisions and it opened the way for the use of the constructive trust to declare rights in land. Also, the decision created the possibility for courts to look behind the parties' formal legal arrangements in the search for their common intentions. The cases post - Gissing ${ }^{17}$ such as Cowcher v Cowcher ${ }^{18}$, Grant v Edwards ${ }^{19}$, and Coombes $v$ Smith ${ }^{20}$ offered a variety of interpretations of the concept of 'common intention' but they were ambiguous and in many aspects contradictory ${ }^{21}$. In 1991 Lord Bridge attempted to clarify the law in the case of Lloyds Bank $v$ Rosset ${ }^{22}$ where he redrew the test on which basis a common intention constructive trust would be formed. According to Lord Bridge, there were two different forms of common intention constructive trusts: common intention based on conduct and common intention based on agreement ${ }^{23}$.

Common intention evidenced by agreement, which is based on Gissing $^{24}$, requires some agreement between the parties which does not have to be in writing. However, it is expected to take place before the purchase (subsequent discussions are less important). Also, the assumption is that there are express discussions rather than emerging but unspoken intentions between the parties ${ }^{25}$. On the other hand, the common intention evidenced by conduct arises where there was no agreement to share beneficial ownership; thus, the courts will have to consider the conduct of the parties ${ }^{26}$. The conduct that Lord Bridge had in mind was based on 'direct contributions to the purchase price' such as payments towards

\footnotetext{
15 A. Hudson, Equity and Trusts, 7th ed., Routledge, 2012, p. 711.

16 [1971] AC 886.

17 Ibid.

18 [1972] 1 All ER 948.

19 [1986] Ch 638.

20 [1986] 1 WLR 808.

21 A. Hudson, Equity and Trusts, 7th ed., Routledge, 2012, p. 717.

22 [1991] 1 AC 107.

23 A. Hudson, Equity and Trusts, 7th ed., Routledge, 2012, p. 717.

24 [1971] AC 886.

25 A. Hudson, Equity and Trusts, 7th ed., Routledge, 2012, p. 716-720.

26 Ibid, pp. 716-720.
} 
initial purchase price or mortgage instalments. According to him, "it is at least extremely doubtful whether anything less will do ${ }^{227}$. In addition a person claiming a common intention constructive trust needs to prove that he suffered detriment.

Rosset $^{28}$ illustrates the difficulties with proving common intention for those seeking an interest in the property ${ }^{29}$. According to Hudson, the rigid test in Rosset $^{30}$ created the possibility for unfairness at the margins. It appears that Lord Bridge forgot that people fall in love and go through variety of life experiences which makes the test contrary to the "very core of equity's flexible ability to do right on a case-by-case basis. '" Hence the courts have not slavishly followed the very clear test set out in Rosset ${ }^{32}$. In 1995, in Midland Bank $v$ Cooke $e^{33}$ Waite LJ stated that, "the duty of the judge is to undertake a survey of the whole course of dealing between the parties relevant to their ownership and occupation of the property...the scrutiny will not confine itself to the limited range of acts of direct contribution... it will take into consideration all conduct which throws light on the question what shares were intended. Only if that search proves inconclusive does the court fall back on the maxim that 'equality is equity ${ }^{34}$. Therefore, Waite LJ suggested that the court should look at the entire course of dealing between the parties rather than solely considering financial contributions to the purchase of the property as a valid representation of the parties' intentions. Subsequently in 2004, in Oxley $v$ Hiscock $^{35}$ it was held that the courts could impute a common intention to the parties where there was no express trust

27 [1991] 1 AC 107 at 133.

28 Ibid.

29 C. Rotherham, "The property rights of unmarried cohabitees: the case for reform" Conv. (2004): 268-292.

30 [1991] 1 AC 107.

31 A. Hudson, Equity and Trusts, 7th ed., Routledge, 2012, p. 728-730.

32 [1991] 1 AC 107; However, there are some cases that followed Rosset - Ivin v Blake [1995] 1 FLR 70, Buggs v Buggs [2003] EWHC 1538 or McKenzie v McKenzie [2003] EWHC 601.

33 [1995] 4 All ER 562.

34 Midland Bank v Cooke [1995] 27 H.L.R. 733 at 745.

35 [2004] EWCA Civ 546. 
declared, by undertaking a survey of the parties' entire course of dealing and by doing what is fair (the unconscionability approach) ${ }^{36}$.

In 2007, in Stack v Dowden ${ }^{37}$ the House of Lords made another attempt to clarify the law in relation to family home trusts. However, it effected very little real change to the law; thus the previous cases are still needed in order to identify the situations in which people other than the legal owners can acquire an equitable interest in a property and also the circumstances in which parties who are joint owners of the legal estate will be eligible for more or less than an equal share in the equitable interest in the home ${ }^{38}$. The majority of judges in $\operatorname{Stack}^{39}$ held that where there is no express trust declared, the court will look for the common intention of the parties to establish the equitable ownership of the home. If the legal title is in joint names, the presumption will be that the equitable interest is similarly held in joint names; if the legal title is held in one person's sole name, the presumption will be that the equitable interest will be owned by that person ${ }^{40}$. It is important to note that each presumption may be rebutted on evidence to the contrary either before or after property was purchased. The decision in Stack ${ }^{41}$ left many questions unanswered and the court missed a chance to clarify the law in relation to family home trusts ${ }^{42}$. Gardner \& Davidson ${ }^{43}$ argued that Baroness Hale did not provide enough explanation on when should the court infer and impute common intention. Therefore, the judgment of the Supreme Court in Jones v Kernott ${ }^{44}$ was long awaited because it was primarily concerned with interpreting Stack $v$ Dowden ${ }^{45}$ and with solving some of the issues that arose post-Stack ${ }^{46}$.

\footnotetext{
36 A. Hudson, Equity and Trusts, 7th ed., Routledge, 2012, p. 707-708.

37 [2007] UKHL 17.

38 A. Hudson, Equity and Trusts, 7th ed., Routledge, 2012, p. 767.

39 Stack v Dowden [2007] UKHL 17.

40 A. Hudson, Equity and Trusts, 7th ed., Routledge, 2012, p. 766-770.

${ }^{41}$ Stack v Dowden [2007] UKHL 17.

42 A. Hudson, Equity and Trusts, 7th ed., Routledge, 2012, p. 766-768.

43 S. Gardner \& K.M. Davidson, “The future of Stack v Dowden” L.Q.R. (2011):
} 13-19.

44 [2011] UKSC 53.

45 Stack v Dowden [2007] UKHL 17.

46 Ibid. 
The law relating to the home is an extraordinary mixture of ingredients and the case law is very complicated ${ }^{47}$. The aim of this dissertation is to demonstrate that although the case of Jones $v$ Kernott ${ }^{48}$ clarified a number of aspects of Stack $v$ Dowden ${ }^{49}$, it also raised a new set of concerns. This will be achieved by analysing the development of the law in relation to family home trusts from the case of Pettitt $v$ Pettitt ${ }^{50}$ up until the most recent judgment of Baroness Hales, Lord Walker, Lord Collins, Lord Kerr, and Lord Wilson in Jones $^{51}$. The dissertation will be divided into four chapters: 'Early Case Law', 'Developments in Lloyds Bank v Rosset and post-Rosset', 'Developments in Stack v Dowden and post-Stack', and 'The decision in Jones v Kernott'.

\section{EARLY CASE LAW}

\section{Pettitt v Pettitt [1970]}

Many of the core cases in 1970s that began the process of shaping the modern law in relation to the family home, concerned married couples and were based on resulting trust principles ${ }^{52}$. The first was Pettitt $v$ Pettitt ${ }^{53}$ where, as noted by Lord Wilson in Jones $v$ Kernott ${ }^{4}$, Lord Diplock sought to develop the law in a way similar to that achieved in Stack v Dowden ${ }^{55}$.

In Pettitt $^{56}$ a wife purchased a cottage in her sole name, having provided the entire purchase price. Her husband however performed renovation works and spent a lot of his money on improving the cottage. When they separated, the husband sought an order under s 17 of the Married

\footnotetext{
47 A. Hudson, Equity and Trusts, 7th ed., Routledge, 2012, p. 702-704.

48 [2011] UKSC 53.

49 [2007] UKHL 17.

50 [1970] A.C. 777.

51 [2011] UKSC 53.

52 A. Hudson, Equity and Trusts, $7^{\text {th }}$ ed., Routledge, 2012, p. 710-711.

53 [1970] A.C. 777.

54 [2011] UKSC 53 at 80.

55 [2007] UKHL 17.

56 [1970] A.C. 777.
} 
Women's Property Act 1882 in order to claim an equitable interest in the property. The registrar held that he was entitled to share in proceeds to the extent of $£ 300$. The Court of Appeal affirmed that decision. However, the House of Lords held that the works performed by Mr Pettitt were not sufficiently important for him to gain an equitable interest in the property.

Lord Diplock said that, "it would ... be an abuse of the legal technique for ascertaining or imputing intention to apply to transactions between the post - war generation of married couples 'presumptions' which are based upon inferences of facts which earlier generation of judges drew as to the most likely intentions of earlier generations of spouses belonging to the propertied class of a different social era ${ }^{35}$. Thus, he argued that the modern view is to move

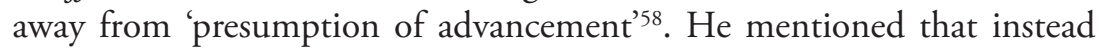
the court should ascertain the 'common intention' by examining the facts and imputing an intention to the parties. ${ }^{59}$ However, the majority in Pet$t_{i t t}{ }^{60}$ criticised that view and the concept of 'imputation', which was to be later appreciated in Stack $v$ Dowden ${ }^{61}$ and Jones $v$ Kernott ${ }^{62}$.

In addition, the House of Lords in Pettitt ${ }^{63}$ did not follow the judgment of Lord Denning sitting in the Court of Appeal who wanted to extend the use of constructive trusts - "it is not correct to look and see whether there was any bargain in the past, or any expressed intention... I prefer to take the simple test: what is reasonable and fair in the circumstances as they have developed, seeing that there are circumstances which no one contemplated

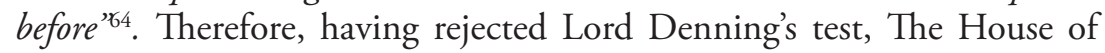
Lord decided the case on the resulting trust principles ${ }^{65}$.

57 Ibid, at 824 .

58 The law on resulting trusts presumed that where a husband passed a property to his wife, he intended to make a gift to her (presumption of advancement). This presumption was used by earlier generation of judges in relation to the family home.

59 Lord Walker in Stack v Dowden [2007] UKHL 17 at 18.

${ }^{60}$ [1970] A.C. 777.

61 [2007] UKHL 17.

${ }^{62}$ [2011] UKSC 53.

63 [1970] A.C. 777.

${ }^{64}$ Pettitt v Pettitt [1968] 1 W.L.R. 443 at 449.

65 A. Hudson, Equity and Trusts, 7th ed., Routledge, 2012, p. 711. 
Lord Reid said that, "In reaching a decision the court...cannot find that there was some thought in the mind of a person which never was there at all. The court must find out exactly what was done or what was said and must then reach conclusion as to what was the legal result." "66. Hence he argued, and it was the view of the majority, that the court should only be concerned with the identification of parties' real intention rather than imputing it with reference to what the parties would have decided had they thought about the matter ${ }^{67}$. The importance of the decision in Pettitt ${ }^{68}$ lies in the fact that it began the process of staking out a modern code of rules to deal with the allocation of equitable interests in the family home ${ }^{69}$.

\section{Gissing v Gissing [1970]}

The facts of the case were that the parties had been married since 1935. Mrs Gissing worked throughout the marriage as a secretary at a firm of printers. In 1946, Mrs Gissing obtained employment for Mr Gissing with the firm where she worked. In 1951, couple bought a house in the husband's sole name. The purchase price was predominantly paid by a mortgage in husband's name; however, Mrs Gissing contributed to the furniture. Mr Gissing left her in 1961 for another woman. Consequently, the wife sought a declaration that she had an equitable interest in the property. The Court of Appeal held by majority that the wife was entitled to a halfshare in the house. However, the House of Lords reversed that decision and held that Mrs Gissing made no contribution to the acquisition of the matrimonial home and thus acquired no beneficial interest in the property.

In Gissing $g^{70}$, Lord Diplock held that Pettitt ${ }^{71}$ was not correct because their Lordships found it impossible to impute a common intention where there was no evidence of any express agreement between parties ${ }^{72}$. He mentioned that in circumstances where the property was bought in a sole

66 Pettitt v Pettitt [1970] A.C. 777 at 804.

${ }^{67}$ Virgo, G. (2012) 'The Principles of Equity \& Trusts' 1st ed., Oxford University Press, 326-328.

68 [1970] A.C. 777.

69 A. Hudson, Equity and Trusts, 7th ed., Routledge, 2012, p. 711.

70 [1971] AC 886.

71 Ibid, at 904 .

72 Ibid, at 904. 
name of one of the spouse and there was no express agreement between spouses as to how the share of another spouse was to be quantified, "the court must first do its best to discover from the conduct of the spouses whether any inference can reasonably be drawn as to the probable common understanding about the amount of the share of the contributing spouse upon which each must have acted in doing what each did... it is only if no such inference can be drawn that the court is driven to apply as a rule of law, and not as inference of fact, the maxim 'equality is equity', and to hold that the beneficial interest belongs to the spouses in equal shares. "3. Therefore Lord Diplock suggested that where the search for evidence of express intention in this regard proves inconclusive, the court might legitimately use the maxim that 'equality is equity' and award the parties equal shares in the property. Lord Walker noted that although Lord Diplock used the word 'infer' rather than 'impute' in Gissing ${ }^{74}$, the substance of the reasoning was essentially the same as Lord Diplock's reasoning in Pettitt ${ }^{75}$ where he was in minority ${ }^{76}$. In his article published in 2004, Rothertham argued that a failure to set clearer guidelines left the law in an unacceptably unpredictable state ${ }^{77}$.

In addition, Lord Diplock apparently equated resulting and constructive trusts despite the fact that in Pettitt $^{78}$ he dismissed the resulting trust as old-fashioned and inappropriate ${ }^{79}$, and this according to Thompson, has later led to a conceptual confusion ${ }^{80}$. Hence it can be argued that Lord Diplock did not follow Lord Hodson's view from Pettitt ${ }^{81}$ that the law should strive for certainty and not permit too much uncertainty.

Gissing $^{82}$ is the leading case that created the possibility of looking behind the formal arrangements between the parties to uncover their

73 Gissing v Gissing [1971] AC 886 at 908.

${ }^{74}$ [1971] AC 886.

75 Ibid.

76 Stack v Dowden [2007] UKHL 17 at 20.

77 C. Rotherham, "The property rights of unmarried cohabitees: the case for reform" Conv. (2004): 268-292.

78 [1971] AC 886.

79 Stack v Dowden [2007] UKHL 17 at 19.

80 Thompson, M.P. 'Case Comment: Constructive trusts, estoppel and the family home” Conv. 2004, Nov/Dec, 496-507.

81 [1970] AC 777.

82 [1971] AC 886. 
common intentions as to the allocation of rights in their home ${ }^{83}$. Hudson noted that, "this decision has become the central text in this area, which establishes the principle that the common intention of the parties is to be taken as the root of any equitable interest in the property's4. Also, the adoption of language 'common intention' by Lord Diplock allowed the use of the constructive trust for the granting of rights in land, rather than the resulting trust which would grant only an equitable interest in proportion to the plaintiff's contribution to the purchase price ${ }^{85}$. According to Mee, Lord Diplock in Gissing ${ }^{86}$ developed the unprincipled and convoluted common intention doctrine in a well-meaning attempt to give more discretion to judges and to improve the claimants' chances of establishing an equitable interest in the property ${ }^{87}$. Even though there have been many cases in House of Lords and Court of Appeal following Gissing ${ }^{88}$, all judges have used Gissing ${ }^{89}$ as a starting point for judgments albeit they tend to contradict one another ${ }^{90}$.

\section{Cowcher v Cowcher [1971]}

The case law that surrounded the decision in Gissing ${ }^{91}$ offered a dispersed reading of the nature of the constructive trust. In Cowcher $v$ Cowcher, ${ }^{92}$ Bagnall J sought to conceptualise the different approaches to the form of constructive trust used in cases of common intention. ${ }^{93}$ The facts of the case were that a married couple bought a house for $£ 12,000$ in 1963. The house was conveyed to the husband's sole name. It was agreed that wife should be treated as having provided $£ 4,000$, which was paid in cash. The remaining $£ 8,000$ was borrowed by the husband from LMAC

${ }^{83}$ A. Hudson, Equity and Trusts, 7th ed., Routledge, 2012, p. 715.

84 Ibid, pp. 713.

85 Ibid, 713-716.

86 [1971] AC 886.

${ }^{87}$ J. Mee, "Case Comment: Jones v Kernott: inferring and imputing in Essex" Conv. (2012): 167-180.

88 [1971] AC 886.

89 Ibid.

90 A. Hudson, Equity and Trusts, 7th ed., Routledge, 2012, p. 713-716.

91 [1971] AC 886.

92 [1972] 1 W.L.R. 425.

93 A. Hudson, Equity and Trusts, 7th ed., Routledge, 2012, p. 715-717. 
secured by a mortgage of the house and a 25-year endowment policy on the life of the husband. The wife paid some instalments when husband was unable to do so. The marriage was dissolved in 1971 and the wife claimed a half share in the house whereas the husband contended that she was entitled only to one-third. It was held by the court that wife was only entitled to one-third of the proceeds ${ }^{94}$.

Bagnall J said that, "I am convinced that in determining...property rights, the only justice that can be attained by mortals...is...the justice which flows from the application of sure and settled principles...otherwise, no lawyer could safely advise on his client's title and every quarrel would lead to a law suit"s. Hence, he argued that equity is now measured and can no longer behave purely on the basis of the chancellor's discretion which was a clear departure from Denning's view ${ }^{96}$. Also, he strived for a greater certainty and clarity in the law. According to Bagnall J, proprietary rights "are not to be determined according to what is reasonable, fair, or just in all the circumstanc$e s^{\text {'n7 }}$. Thus he asserted the position of Lord Reid from Pettitt ${ }^{8}$ who was also against imputation of parties' intentions. He argued that although a decision might appear to be 'unfair', it did not make it 'unjust' ${ }^{\prime}$.

Furthermore, it was held that the concepts of constructive and resulting trusts could be taken to be synonymous ${ }^{100}$ and the nature of the common intention formed between the parties was said to be either as the equitable interest which each party would receive, which would be derived from the conduct of the parties if no express agreement could be proved ('interest consensus), or as to the size of the contribution which each party would make towards the purchase price of the property ('money consensus' $)^{101}$. The 'money consensus' is not derived from conduct, but rather is based on express agreement to the amount of money paid by each party

94 Cowcher v Cowcher [1972] 1 W.L.R. 425.

95 Ibid, at 430.

96 R. Clements, A. Abass, Equity and Trusts: Text, Cases and Materials, 2nd ed., Oxford University Press, 2011, p. 19.

${ }_{97}$ Cowcher v Cowcher [1972] 1 W.L.R. 425 at 429.

98 Lord Reid in Pettitt v Pettitt [1970] A.C. 777 at 793.

99 A. Hudson, Equity and Trusts, 7th ed., Routledge, 2012, p. 716.

100 Ibid, pp. 716.

101 Cowcher v Cowcher [1972] 1 W.L.R. 425 at 436. 
towards the purchase price of the property ${ }^{102}$. This type of common intention constructive trust is a mixture of a resulting trust which looks at the parties' contributions to the purchase price of the property and a constructive trust which looks at the conscionability of allowing one party to take an unfair benefit from the understanding between the parties as to ownership of the property ${ }^{103}$.

Therefore, Bagnall J did not only hold that constructive and resulting trusts could be taken to be synonymous but he also divided the concept of 'common intention' into 'money consensus' and 'interest consensus'. Moreover, he supported the position of Lord Reid from Pettitt ${ }^{104}$ on imputation of parties' intention. According to Hudson ${ }^{105}$, the approach from Cowcher ${ }^{106}$ had not been followed explicitly for some time until the decision of the Court of Appeal in Midland Bank v Cooke ${ }^{107}$.

\section{Grant v Edwards [1986]}

The decision in Grant $v$ Edwards ${ }^{108}$ offered a different reading of the concept of 'common intention' to the previous cases. Chadwick LJ described it as 'an important turning point' that provided a 'helpful guidance' ${ }^{109}$, while Gibson LJ found the judgment 'particularly helpful and illuminating' ${ }^{110}$. What is more, it was referred to with 'obvious approval' in Lloyds Bank $v$ Rosset ${ }^{111}$ and in Midland Bank v Cooke ${ }^{112}$.

In this case, the plaintiff who was separated from the husband set up home with the defendant. The house was conveyed into the joint names of the defendant and his brother, who had no beneficial interest in the property and had been joined solely for the purpose of assisting in obtaining

102 Springette v Defoe (1992) 24 HLR 552.

103 A. Hudson, Equity and Trusts, 7th ed., Routledge, 2012, p. 716.

104 [1970] A.C. 777 at 793.

105 A. Hudson, Equity and Trusts, 7th ed., Routledge, 2012, p. 715-716.

106 [1972] 1 W.L.R. 425.

107 [1995] 4 All ER 562.

108 [1986] Ch 638.

109 Oxley v Hiscock [2004] EWCA Civ 546 at para 29, 56.

${ }_{110}$ Drake v Whipp [1996] 28 H.L.R. 531 at 536.

111 [1991] 1 AC 107.

112 [1995] 4 All ER 562. 
a mortgage on property. The defendant told the plaintiff that the reason why the title to a house was not taken in their joint names was because it would cause her prejudice in the matrimonial proceedings which were pending against her husband. The plaintiff made substantial contributions to the general household expenses. The parties separated in 1980 and the plaintiff claimed a beneficial interest in the house. The Court of Appeal held that the plaintiff was entitled to a half interest in the house.

Nourse LJ explained that, "the facts appear to me to raise a clear inference that there was an understanding between the plaintiff and the defendant... that the plaintiff was to have some sort of proprietary interest in the house"113. In 2009, Barnes ${ }^{114}$ concluded that this approach was clearly based on an objective assessment of intention that was described by Lord Diplock in Gissing ${ }^{115}$. The somewhat heretical conclusion in this case was that it is possible that purely personal acts will be evidence of a 'common intention'116. Browne-Wilkinson VC held that, "the plaintiff has acted to her detriment in reliance on the common intention that she had a beneficial interest in the house and accordingly she has established such beneficial interest"117 Hence, the claimant was able to succeeded in establishing a beneficial interest equal to a one half share on the basis of constructive trust (per Nourse LJ) or proprietary estoppel (per Browne-Wilkinson VC) ${ }^{118}$.

Browne-Wilkinson VC restated Lord Diplock's principles from Gissing $^{119}$ because "there has been a tendency over the years to distort the principles laid down in the speech of Lord Diplock... by concentrating on only part of his reasoning" 20 and he formulated a principle that was as follows: if the legal estate in the joint home is vested in the legal owner, the claimant in order to establish a beneficial interest has to establish a constructive trust by showing that it would be inequitable for legal owner to claim

113 Grant v Edwards [1986] Ch 638 at 649.

114 Luke Barnes, "Defining Detriment", Family Law Week, (2009) on http://www. familylawweek.co.uk/site.aspx?i=ed34330 last accessed on 20.09.2016.

115 [1971] AC 886 at 906.

116 A. Hudson, Equity and Trusts, $7^{\text {th }}$ ed., Routledge, 2012, p. 722-723.

117 Grant v Edwards [1986] Ch 638 at 656.

118 Chadwick LJ in Oxley v Hiscock [2004] EWCA Civ 546 at 30.

119 [1971] AC 886.

120 Browne Wilkinson VC in Grant v Edwards [1986] Ch 638 at 654. 
sole beneficial ownership. This requires two matters to be demonstrated: common intention and detriment ${ }^{121}$. Furthermore, Browne-Wilkinson VC suggested that, "useful guidance may in future be obtained from the principles underlying the law of proprietary estoppel which in my judgment are closely akin to those laid down in Gissing" Thus there is a reasonably long pedigree underpinning the idea that common intention constructive trusts and proprietary estoppel are based on similar principles ${ }^{122}$. Nonetheless, Panesar argues that there is a clear difference between the two concepts ${ }^{123}$.

The doctrine of proprietary estoppel gives an interest to a person who "has been induced to suffer detriment in reliance on a representation (or some assurance) that she would acquire some rights in the property as a result"124. As opposed to constructive trust and resulting trust which are 'institutional' trusts, the doctrine of proprietary estoppel may give a different kind of right $^{125}$.

Therefore, although Nourse LJ and Browne-Wilkinson VC decided the case on different principles, they both held that plaintiff had some sort of proprietary interest in the house. The case is important because Browne-Wilkinson VC considered the concepts of 'common intention constructive trust' and 'proprietary estoppel' to be similar. Thus, the fact that in Cowcher ${ }^{126}$ the common intention constructive trust was compared to resulting trust while in this case it was compared to proprietary estoppel proves that the case law after Pettitt ${ }^{127}$ and Gissing ${ }^{128}$ was inconsistent and unclear. Browne-Wilkinson VC emphasised the fact that Lord Diplock's principles had been distorted over the years and that is why he decided to restate them.

121 A. Hudson, Equity and Trusts, 7th ed., Routledge, 2012, p. 721-722.

122 Ibid, pp. 759-760.

123 Panesar, S. (2012) 'Exploring Equity and Trusts', 2nd ed., Pearson Education Ltd., pp. 406.

124 A. Hudson, Equity and Trusts, 7th ed., Routledge, 2012, p. 743.

125 Ibid, p. 743.

126 [1972] 1 W.L.R. 425.

127 [1970] AC 777.

128 [1971] AC 886. 


\section{Conclusion}

The cases prior to Lloyds Bank v Rosset ${ }^{129}$ offered a variety of readings of the concept of 'common intention,' which were often contradictory. Pettitt $v$ Pettitt ${ }^{130}$ was the first case that began the process of staking out the modern codes of rules to deal with the allocation of equitable interests in the family home while Gissing $v$ Gissing ${ }^{131}$ introduced the concept of 'common intention' and provided courts with the possibility of looking behind the formal arrangements between the parties to uncover their common intentions as to the allocation of property rights in their home. The cases post - Gissing ${ }^{132}$ such as Cowcher v Cowcher ${ }^{133}$ and Grant v Edwards ${ }^{134}$ prove that the common intention constructive trust played 'fast and loose' with a variety of concepts borrowed from proprietary estoppel, constructive trusts, and resulting trusts and there were no clear principles and guidelines to be followed ${ }^{135}$. They emphasise the inconsistency and unpredictability of the law surrounding family home trusts before Rosset ${ }^{136}$.

\section{DEVELOPMENTS IN LLOYDS BANK V ROSSET AND POST-ROSSET}

\section{Lloyds Bank v Rosset [1990]}

As opposed to the earlier cases, the House of Lords decision in Lloyds Bank $v$ Rosset ${ }^{137}$ provided a more rigid statement of the nature of the common intention constructive trust, which both tided and confused this area of law ${ }^{138}$. The case concerned a married couple who purchased a semi-derelict farmhouse. The property was put in the husband's sole name but the

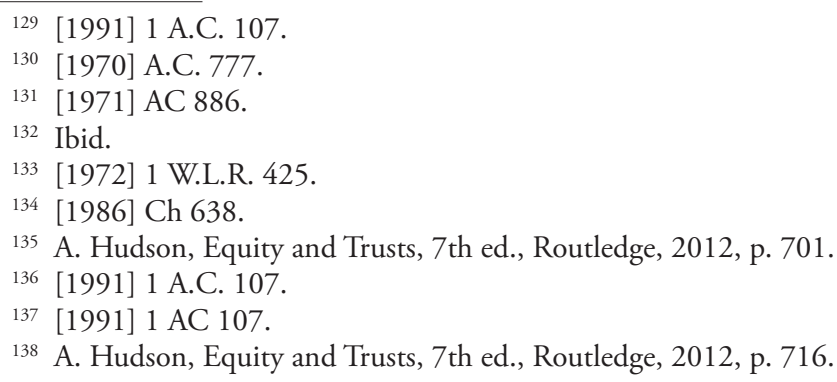


house was to be a family home and renovated as a joint venture. The wife oversaw all of the building work. Mr Rosset acquired the property with a mortgage registered in his sole name while Mrs Rosset had been led to believe that the property was to be acquired without it. Mr Rosset was unable to repay the loan and the bank sought repossession of the property. Mrs Rosset claimed to have an equitable interest in it. It was held that Mrs Rosset acquired no equitable interest in the house because activities such as supervising renovation work were not enough to acquire equitable interest ${ }^{139}$.

Lord Bridge held that, "[the] fundamental question which must always be resolved is whether... there has at any time prior to acquisition, or exceptionally at some later date, been any agreement, arrangement or understanding reached between [the parties] that the property is to be shared beneficially" 40 which as he later noted should "be based on evidence of express discussion between the partners, however imperfectly remembered and however imprecise their terms" $" 14$. Hence, Lord Bridge accepted that common intention could arise from some agreement between parties but he noted that discussions sufficient to constitute such 'agreement' are expected to have been carried out before the purchase of the property. Also, the assumption is that there are express discussions rather than "emerging but unspoken intentions between the parties" ${ }^{142}$. Hudson commented that this approach does not recognise the reality of relationships in which couples go through a variety of life experiences ${ }^{143}$.

Lord Bridge said that in the absence of an express agreement to share beneficial ownership, "the court must rely entirely on the conduct of the parties both as the basis from which to infer a common intention to share the property beneficially and as the conduct relied on to give rise to a constructive trust"144. Therefore, the parties' conduct can give rise to establishing common intention. The only 'conduct' that he had on mind were direct contributions

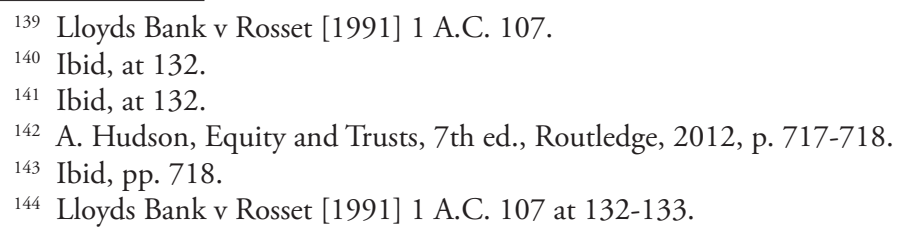


to the purchase price because "it is at least extremely doubtful whether anything less will do"145; thus supervising renovation works is not sufficient. It can be argued that the type of 'conduct' envisaged by Lord Bridge is very limited ${ }^{146}$. In addition, before the claimant can demonstrate any type of common intention constructive trust, he needs to prove that he suffered detriment ${ }^{147}$.

Lord Bridge created two different categories of common intention constructive trust: common intention based on conduct and common intention based on agreement, and he clearly intended to compact constructive trust and proprietary estoppel together in a single doctrine ${ }^{148}$. Even though the test in Rosset $^{149}$ does have the merit of greater clarity than many of the other decided cases ${ }^{150}$, "it had not commanded complete obedience in the lower courts nor did it accord with the preceding doctrine." However, if the test were consistently followed, those who made non-financial contributions in the course of relationship would not have a basis to make a claim for an interest in the property ${ }^{152}$. Although the decision was often criticised, it was never explicitly overruled ${ }^{153}$. Rotherham argued that in Rosset ${ }^{154}$ the place of the common intention constructive trust was secured most decisively ${ }^{155}$.

145 Lord Bridge in Lloyds Bank v Rosset [1991] 1 A.C. 107 at 133.

146 A. Hudson, Equity and Trusts, 7th ed., Routledge, 2012, p. 720.

${ }_{147}$ Lloyds Bank v Rosset [1991] 1 A.C. 107 at 132.

148 A. Hudson, Equity and Trusts, 7th ed., Routledge, 2012, p. 626.

149 [1991] 1 AC 107.

150 A. Hudson, Equity and Trusts, 7th ed., Routledge, 2012, p. 723.

151 Ibid, pp. 699.

152 C. Rotherham, "The property rights of unmarried cohabitees: the case for reform" Conv. (2004): 268-292.

153 A. Hudson, Equity and Trusts, 7th ed., Routledge, 2012, p. 770.

154 [1991] 1 A.C. 107.

155 C. Rotherham, "The property rights of unmarried cohabitees: the case for reform" Conv. (2004): 268-292. 


\section{Huntingford v Hobbs [1992]}

After the decision in Lloyds Bank $v$ Rosset ${ }^{156}$ there has been a splintering

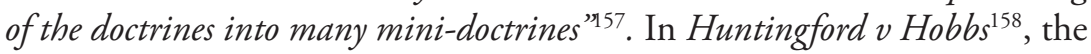
Court of Appeal presented a 'balance sheet approach,' which allowed the court to calculate parties' equitable interests in the home based on the list of their financial contributions towards the property. This approach differed from the one in Rosset ${ }^{159}$ because parties' contributions could be made after the acquisition of the estate and did not have to be directed solely at acquiring interests in $\mathrm{it}^{160}$.

The plaintiff and the defendant were not married but lived together. The defendant was divorced and had been living in her former matrimonial home. The plaintiff was a music teacher and moved in to live with the defendant. Not long after that parties decided to sell the house and move to a different one. They bought a property for $£ 63,250$; the defendant provided $£ 38,860$ from the proceeds of sale of her home and a joint mortgage for $£ 25,000$ was taken out. The defendant did not have any income and the plaintiff paid for most of the household bills and mortgage repayments. In 1988, the plaintiff left the defendant to marry another woman. The plaintiff claimed a joint tenancy on the basis of the terms of conveyance. The County Court held that the plaintiff's equitable interest in the property equalled $£ 3,500$; hence, the plaintiff appealed.

Slade LJ held that, "the words used in the transfer in the present case did not constitute a declaration of trust... Nevertheless...parties must have intended that [plaintiff] should have some beneficial ownership in the property"161 Hence he rejected the plaintiff's claim that the joint tenancy stemmed from the terms of the conveyance but he acknowledged that the plaintiff was entitled to some beneficial ownership in the property. Slade LJ distinguished this case from Gissing ${ }^{162}$ because here the purchase was made in joint names, not in the sole name of one party. He went on to say that, "the

156 [1991] 1 A.C. 107.

157 A. Hudson, Equity and Trusts, 7th ed., Routledge, 2012, p. 707.

158 [1993] 1 FLR 736.

159 [1991] 1 A.C. 107.

160 A. Hudson, Equity and Trusts, 7th ed., Routledge, 2012, p. 730.

161 Huntingford v Hobbs [1992] 24 HLR 652 at 657.

162 [1971] AC 886. 
proper common intention to impute to them is a common intention as at the date of the purchase that Mrs Hobbs should be treated as having contributed her cash contribution, Mr Huntingford should be treated as having contributed the whole of the sum borrowed on mortgage, and that the property should be owned by the two of them in shares proportionate to such contributions... and Mr Huntingford... to be credited for $£ 2000$ paid by him for erection of the conservatory "163. Thus he straightforwardly looked at the amounts of financial contributions by the parties towards the property but as opposed to Rosset ${ }^{164}$, not only contributions to the acquisition were taken into account but also subsequent expenditure such as money spent on the conservatory after the purchase of property. The 'balance sheet approach' was primarily based on resulting trust principles but the subsequent changes of intention were effected by means of constructive trust ${ }^{165}$. Hudson concluded that the Slade LJ's judgment "demonstrated an attitude based not on 'an abstract notion of justice' but on a rough approximation of what each party had contributed ${ }^{\text {1166 }}$ before and after acquisition while Norman in her article noted that in this case "equity appears to have been achieved" the decision in this case differed substantially from the one in Rosset ${ }^{168}$, it found some academic support.

\section{Midland Bank v Cooke [1995]}

In this case the Court of Appeal once again visited the principle from Gissing ${ }^{169}$ whereby one person can claim an equitable interest in a property legally owned by another ${ }^{170}$. Mr and Mrs Cooke purchased a house in the husband's sole name. The purchase price was funded by a mortgage (£6,450), Mr Cooke’s cash contribution (£950) and a wedding gift

163 Huntingford v Hobbs [1992] 24 HLR 652 at 659-661.

164 [1991] 1 A.C. 107.

165 A. Hudson, Equity and Trusts, 7th ed., Routledge, 2012, p. 735.

166 Ibid, pp. 723.

167 H. Norman, "Case Comment: Resulting trusts - determining beneficial entitlement” Conv. (1992): 347-354.

168 [1991] 1 AC 107.

169 [1971] AC 886.

170 S. Gardner, "Case Comment: Fin de siècle chez Gissing v Gissing” L.Q.R (1996): 378-383. 
$(£ 1,100)$. They then replaced the mortgage by a different one and Mrs Cooke signed a consent form to subordinate any interest she might have to the bank's mortgage. The plaintiff demanded repayment of $£ 52,000$ and sought possession. Mrs Cooke claimed an equitable interest in the house to override bank's claim. The County Court dismissed the plaintiff's claim for possession and held that Mrs Cooke's beneficial interest was 6.47 per cent of the house which reflected half of the gift from her parents-in-law $(£ 500)$. Mrs Cooke appealed against the quantification of the beneficial interest and the plaintiff cross-appealed claiming that she had no interest in the property ${ }^{171}$. Waite LJ said that, "[parties'] presumed intention was to share the beneficial interest in the property in equal shares. I reach this result without the need to rely on equitable maxim as to equality'172. Hence, the court determined that Mrs Cooke was entitled to an equal share in the house. Gardner argued that it is not clear whether Waite LJ pursued a fixed or floating analysis ${ }^{173}$. According to Lord Diplock in Gissing ${ }^{174}$, if there is no express agreement between parties as to the quantum of their shares, the court must look for an implied agreement which may take the form either that the parties' shares should be fixed or they should float and be quantified by the court which may decide it on the basis of fairness.

Waite LJ returned to Gissing ${ }^{175}$ without considering Rosset ${ }^{176}$ in detail and held that, "the duty of the judge is to undertake a survey of the whole course of dealing between the parties... The scrutiny will not confine itself to the limited range of acts of direct contribution... "177. He argued that the judge's responsibility is to survey the whole course of dealing of the parties and the court does not need to solely rely on the limited range of acts of direct contribution mentioned in Rosset $^{178}$ that are needed for establishing a ben-

171 Midland Bank v Cooke [1995] 27 H.L.R. 733 at 734-735.

172 Ibid, at 747.

173 S. Gardner, "Case Comment: Fin de siècle chez Gissing v Gissing” L.Q.R (1996):

378-383 at 380 .

174 Lord Diplock in Gissing v Gissing [1971] AC 886 at 908-909.

175 [1971] AC 886.

176 [1991] 1 AC 107.

177 Midland Bank v Cooke [1995] 27 H.L.R. 733 at 745.

178 [1991] 1 A.C. 107. 
eficial interest at first place ${ }^{179}$. Thus, once the existence of a common intention is inferred from a contribution made towards the acquisition of the property, all sorts of contributions to the relationship (not only financial ones) can be considered when quantifying the plaintiff's interest ${ }^{180}$. This is a 'family assets approach', which goes beyond the approach in Rosset ${ }^{181}$.

Waite LJ's reasoning is not technically persuasive ${ }^{182}$. It is based mainly on assertion that it is of the nature of equity that in such circumstances the arrangement could be imputed, even if there was none. This is contradictory to Lord Diplock's judgment from Gissing ${ }^{183}$, where he held that judge must not invent a constructive trust ${ }^{184}$. Dixon noted that Waite LJ's finding is remarkable and hardly supported by authority - "it repeats the heresy perpetrated by Lord Diplock in Pettitt $v$ Pettitt which he then retracted in Gissing $v$ Gissing "185. He argued that decision in Cooke ${ }^{186}$ has done little to clarify the law of resulting and constructive trusts, ${ }^{187}$ while Rotherham said that, "the end result of Midland Bank $v$ Cooke is a highly arbitrary state of affairs" 188 .

\section{Oxley v Hiscock [2004]}

The decision of the Court of Appeal in Oxley $v$ Hiscock ${ }^{189}$ was based on an 'unconscionability approach' which allowed the courts to allocate equitable interests in the home without the need to base their findings

179 A. Hudson, Equity and Trusts, 7th ed., Routledge, 2012, p. 737.

180 C. Rotherham, "The property rights of unmarried cohabitees: the case for reform" Conv. (2004): 268-292.

181 A. Hudson, Equity and Trusts, 7th ed., Routledge, 2012, p. 699.

182 S. Gardner, "Case Comment: Fin de siècle chez Gissing v Gissing” L.Q.R (1996): $378-383$ at 381 .

183 [1971] AC 886.

184 S. Gardner, "Case Comment: Fin de siècle chez Gissing v Gissing” L.Q.R (1996): 378-383.

185 M. Dixon, “Case Comment: A case too far?” Conv. (1997): 66-73.

186 Midland Bank v Cooke [1995] 27 H.L.R. 733.

187 M. Dixon, “Case Comment: A case too far?" Conv. (1997): 66-73.

188 C. Rotherham, "The property rights of unmarried cohabitees: the case for reform" Conv. (2004): 268-292.

189 [2004] EWCA Civ 546. 
on a common intention ${ }^{190}$. In this case, the Court of Appeal "paid further attention to the law whereby a constructive trust may arise over a family home, under Gissing $v$ Gissing and Lloyds Banks v Rosset. "191.

The facts of this case were that in 1991 the unmarried couple purchased a property for $£ 127,000$. Mr Hiscock had contributed $£ 60,000$ and Mrs Oxley had contributed $£ 36,000$ and other outgoings. The house was bought in Mr Hiscock's sole name for fear that it would be vulnerable to a claim from Mrs Oxley's former husband in the event of her death. Despite the solicitor's advice, Mrs Oxley did not formalise her interest in the property. In 2001 the parties separated and the property was sold for $£ 232,000$. The issues arose as to which of them had what equitable interest in the property. The trial judge held that the parties were entitled to equal shares in the house and that it could be inferred from the parties' conduct. Mr Hiscock argued that Mrs Oxley's share should be by way of resulting trust calculated solely on her actual financial contributions.

Chadwick LJ with whom Mance LJ and Scott Baker LJ agreed held that "to declare that the parties were entitled in equal shares would be unfair to Mr Hiscock...I would hold that a fair division of proceeds of sale of the property would be 60\% to Mr Hiscock and 40\% to Mrs Oxley" ${ }^{192}$. Thus Chadwick LJ divided the property in the ratio 60:40 in favour of Mr Hiscock. He argued that in order for the claimant to establish a constructive trust, the claimant had to prove a common intention (express or implied) to share an interest in the property owned by the defendant, along with the evidence of his reliance on that intention. According to Gardner, the sorts of evidence that Chadwick LJ had on his mind were direct contributions to the purchase price. As regards quantification, Chadwick LJ said that in cases where quantum is not dictated by common intention it should be determined by principles of proprietary estoppel and the court should award a fair share for each party having regard to the whole course of dealing between them in relation to that property and this included arrangements to meet the outgoings such as mortgage contributions, repairs or house-

190 A. Hudson, Equity and Trusts, 7th ed., Routledge, 2012, p. 752.

191 S. Gardner, "Case Comment: Quantum in Gissing v Gissing constructive trusts" L.Q.R. (2004): 541-548.

192 Oxley v Hiscock [2004] EWCA Civ 546 at para 74,75. 
keeping. Since in $O x l e y^{193}$ there has been no such common intention, the doctrine of proprietary estoppel applied ${ }^{194}$. Chadwick LJ noted that, "there is no difference in outcome, in cases of this nature, whether the true analysis lies in constructive trust or in proprietary estoppel"195. Hence, he attempted to assimilate the principles underlying constructive trust with proprietary estoppel ${ }^{196}$.

The Oxley ${ }^{197}$ test applies only where parties had a common intention to share a beneficial interest in the property but had no common intention as to the size of their shares ${ }^{198}$. According to Chadwick LJ, reference to common intention to the quantum of the parties' interests is commonly "artificial and an unnecessary fiction" $" 199$ and the court can impute it, which is not a permissible approach under Gissing $v$ Gissing ${ }^{200}$. Chadwick LJ's approach never involved an abandonment of the search for common intention. It was only in a situation where there was no evidence of any discussion between the parties as to the amount of the share which each was to have ${ }^{201}$.

Dyson in his article argued that decision in $\mathrm{Oxley}^{202}$ replaced the traditional resulting trust principles of quantification ${ }^{203}$, while Dixon said that Chadwick LJ's analysis excluded any "meaningful role for resulting trusts in a relationship shared home context. ${ }^{204}$. However, in 2004 Thomson had

193 Oxley v Hiscock [2004] EWCA Civ 546.

194 S. Gardner, "Case Comment: Quantum in Gissing v Gissing constructive trusts" L.Q.R. (2004): 541-548.

195 Oxley v Hiscock [2004] EWCA Civ 546 at para 71.

196 M.P. Thomson, „Case Comment: Constructive trusts, estoppel and the family home" Conv. (2004): 496-507.

197 Oxley v Hiscock [2004] EWCA Civ 546.

198 J. Roche, "Kernott, Stack, and Oxley made simple: a practitioner's view" Conv. (2011): $123-139$ at 129 .

199 Oxley v Hiscock [2004] EWCA Civ 546 at para 71.

200 Gissing v Gissing [1971] AC 886 at 904.

201 J. Smithdale, "Inference, imputation, or both? Confusion persists over beneficial interests in the family home" C.S.L.R. (2011): 74-88 at 86.

202 Oxley v Hiscock [2004] EWCA Civ 546.

203 A. Dyson, "All's fair in love and war: an analysis of the common intention constructive trust” C.S.L.R. (2008): 149-166 at 160.

${ }^{204}$ M. Dixon, "Case Comment: Resulting and constructive trusts of land: the mist descends and rises" Conv. (2005): 79-88 at 84. 
said that although the Court of Appeal in Oxley ${ }^{205}$ determined the quantum of Mrs Oxley's interest on the basis of the court's perception of fairness, it exactly reflected her financial contributions to acquisition of the property. Hence the court was in fact applying resulting trust principles and not proprietary estoppel principles as it had claimed ${ }^{206}$.

Both decisions in Midland Bank $v$ Cooke $^{207}$ and in Oxley ${ }^{208}$ illustrate the judicial attempt to provide judges with the greater discretion. However, although some discretion is inevitable in deciding individual cases, " $a$ systematically discretionary approach to the declaration of proprietary rights seems incongruous with the very basis of property law ${ }^{209}$. Chadwick LJ's approach appears to be more remedial rather than institutional like traditional constructive trusts. It is distinctly different from the Rosset ${ }^{210}$ test, 'balance sheet approach' or 'family assets approach'. As opposed to Rosset ${ }^{211}$ and 'balance sheet cases', the 'unconscionability approach' and 'family assets approach' is concerned with a survey of all of the material circumstances, not only financial contributions. In addition, it was not possible to impute common intention under Rosset ${ }^{212}$ where the court perceived it as 'fair' in a given situation ${ }^{213}$.

Although Gray and Gray hailed $O x$ eyy $^{214}$ as an important breakthrough' $^{215}$, Hudson argued that it is intellectually unsustainable to merge two radically different approaches into one test "whereby one looked first for an agreement between parties and then at the whole course of dealing if no such

${ }^{205}$ Oxley $v$ Hiscock [2004] EWCA Civ 546.

${ }^{206}$ M.P. Thomson, „Case Comment: Constructive trusts, estoppel and the family home" Conv. (2004): 496-507 at 505.

207 [1995] 27 H.L.R. 733.

208 Oxley $v$ Hiscock [2004] EWCA Civ 546.

209 A. Dyson, "All's fair in love and war: an analysis of the common intention constructive trust” C.S.L.R. (2008): 149-166 at 160-161.

210 Lloyds Bank v Rosset [1991] 1 A.C. 107.

211 Ibid.

212 Ibid.

213 A. Hudson, Equity and Trusts, 7th ed., Routledge, 2012, p. 756.

214 Oxley v Hiscock [2004] EWCA Civ 546.

215 K. Gray, S.F. Gray, Elements of Land Law, Oxford University Press, 2005, p. 931. 
agreement could be found. ${ }^{2116}$. He also noted that Rosset ${ }^{217}$ did not intend to permit such a broad survey to be undertaken by the $\operatorname{court}^{218}$.

\section{Conclusion}

Although the test set out in Rosset ${ }^{219}$ was very clear, the courts have not slavishly followed it. Hudson noted that Lord Bridge appeared to forget that people fall in love and go through a variety of life experiences. He also argued that the test in Rosset ${ }^{220}$ is contrary to the equity's flexible ability to consider cases on the case-by-case basis. Consequently, the Court of Appeal moved in a number of different directions presenting a range of more flexible approaches ${ }^{221}$.

In Huntingford $v$ Hobbs $^{222}$, the Court of Appeal presented a 'balance sheet approach,' which differed from Rosset ${ }^{223}$ because parties' financial contributions could be made after the acquisition of the estate and did not have to be directed solely at acquiring interests in it $^{224}$. In Midland Bank $v$ Cooke 225 Waite LJ took a 'family assets approach,' which placed an obligation on the courts to survey the whole course of dealing of the parties with no need to solely rely on the limited range of acts of direct contribution required for establishing a beneficial interest at first place ${ }^{226}$. However in Oxley $v$ Hiscock $^{227}$ which was based on an 'unconscionability approach' Chadwick LJ held that where parties have a common intention to share a beneficial interest in the home but have no common intention as to the size of their shares ${ }^{228}$, courts may allocate equitable interests in

216 A. Hudson, Equity and Trusts, 7th ed., Routledge, 2012, p. 799.

217 Lloyds Bank v Rosset [1991] 1 A.C. 107.

218 A. Hudson, Equity and Trusts, 7th ed., Routledge, 2012, p. 798-799.

219 Lloyds Bank v Rosset [1991] 1 A.C. 107.

220 Ibid.

221 A. Hudson, Equity and Trusts, 7th ed., Routledge, 2012, p. 723, 729, and 730.

222 [1993] 1 FLR 736.

223 [1991] 1 A.C. 107.

224 A. Hudson, Equity and Trusts, 7th ed., Routledge, 2012, p. 730.

225 [1995] 27 H.L.R. 733.

226 A. Hudson, Equity and Trusts, 7th ed., Routledge, 2012, p. 737.

227 [2004] EWCA Civ 546.

228 S. Gardner, "Case Comment: Quantum in Gissing v Gissing constructive trusts" L.Q.R. (2004): 541-548. 
that property without the need to base their findings on a common inten$\operatorname{tion}^{229}$. It can be argued that the significant number of conflicting doctrines established after Rosset ${ }^{230}$ indicated that the state of law surrounding family home trusts remained ambiguous and required further clarification.

\section{DEVELOPMENTS IN STACK V DOWDEN}

\section{Stack v Dowden [2007]}

Although the decision of the House of Lords in Stack v Dowden ${ }^{231}$ was truly ground-breaking 232 and "made the newspapers and the headlines on BBC Radio 4 news, ${ }^{233}$ it did not overrule any of the preceding law ${ }^{234}$. The case concerned an unmarried couple who cohabited for 27 years. Ms Dowden was a successful engineer and Mr Stack a builder and decorator. The first house they lived in had been bought in Ms Dowden's sole name. They later sold it and bought a property in their joint names. The purchase was financed as to 65 per cent by Ms Dowden and as to 35 per cent by a mortgage. Ms Dowden paid off about $60 \%$ of the capital on the mortgage while Mr Stack paid for the mortgage interest instalments. They both had separate bank accounts. When they separated, the issue arose as to whether they were equitable joint tenants. The trial judge said that they were joint tenants. The Court of Appeal held that Mr Stack was only entitled to a 35 per cent share; hence he appealed. The House of Lords upheld the judgment that the equitable interest in the house should be divided in the ratio 65:35 in favour of Ms Dowden ${ }^{235}$.

229 A. Hudson, Equity and Trusts, 7th ed., Routledge, 2012, p. 752.

230 Lloyds Bank v Rosset [1991] 1 A.C. 107.

231 [2007] UKHL 17.

${ }^{232}$ T. Etherton, "Constructive trusts: a new model for equity and unjust enrichment" C.L.J. (2008): 265-287 at 287.

233 A. Hudson, Equity and Trusts, 7th ed., Routledge, 2012, p. 766.

234 Ibid, p. 799.

235 W. Swadling, "Case Comment. The common intention constructive trust in the House of Lords: an opportunity missed” L.Q.R. (2007): 511-518 at 512-514 and A. Hudson, Equity and Trusts, 7th ed., Routledge, 2012, p. 767. 
In Stack ${ }^{236}$, their Lordships placed an emphasis on ascertaining the parties' common intention in disputes over cohabited homes ${ }^{237}$. Speaking for the majority, Baroness Hale took the view that, where there is no express trust declared the court will look for the common intention of the parties to establish the equitable ownership of the home. If the legal title to a cohabited home is in joint names, the presumption will be that the equitable interest is similarly held in joint names; if the legal title is held in one person's sole name, the presumption will be that the equitable interest is owned by that person ${ }^{238}$. It is important to note that each presumption may be rebutted on evidence to the contrary either before or after property was purchased. All of the law prior to Stack ${ }^{239}$ is still relevant when identifying the situations in which parties' equitable shares can be greater or less than an equal share in that beneficial interest, and also when identifying situations in which people other than legal owners can acquire equitable interest in the property ${ }^{240}$.

Baroness Hale noted that she would be prepared to impute intention if necessary ${ }^{241}$. Lord Walker concluded that there is no meaningful distinction between inferring and imputing intention and both are acceptable while Lord Neuberger in his dissenting judgment argued that there is a clear difference between these two concepts and that courts cannot impute intention to parties when resolving property disputes over cohabited homes ${ }^{242}$. Therefore, it can be argued that the court failed to define its clear stance in relation to "inferring" and "imputing" common intention.

Baroness Hale said that when searching for the parties' common intention to hold a property as equal beneficiaries, the court should not only take into account their financial contributions in relation to property but also other factors, for instance, the purpose for which the home was acquired, the nature of parties' relationship, or how the purchase was

236 Stack v Dowden [2007] UKHL 17.

237 M. Harding, "Defending Stack v Dowden” Conv. (2009): 309-325 at 312.

238 A. Hudson, Equity and Trusts, 7th ed., Routledge, 2012, p. 766-767.

239 Stack v Dowden [2007] UKHL 17.

240 A. Hudson, Equity and Trusts, 7th ed., Routledge, 2012, p. 772.

241 M. Harding, "Defending Stack v Dowden” Conv. (2009): 309-325 at 313.

242 Ibid, at 313. 
financed ${ }^{243}$. However, Baroness Hale argued that, "financial factors weighted more heavily than any other factor ${ }^{244}$. Thus she emphasised the importance of financial contributions.

The majority in Stack245 "sent out mixed messages about whether the common intention constructive trust found by them was an institutional constructive trust or a remedial one ${ }^{246}$. Baroness Hale speaking for the majority, rejected the approach of Chadwick LJ in Oxley v Hiscock ${ }^{247}$ that each party is entitled to a "share which the court considers fair having regard to the whole course of the dealing between them in relation to the property ${ }^{2248}$ and this could indicate that their Lordship placed the case within the institutional model. Nonetheless, the references of Lord Walker and Baroness Hale to the relevance of 'imputed' intentions and bargain of the parties are inconsistent with an institutional trust ${ }^{249}$. Hence, the common intention constructive trust found by the court was neither institutional nor remedial but could be considered as a mixture of both.

Baroness Hale who delivered the leading speech took an approach of a family lawyer but it was Lord Walker who had the most experience of trust law. According to Hudson the fact that he decided to delete most of his draft opinion was a 'tragedy'. Lord Walker presented his judgment as a footnote to the judgment of Baroness Hale. Some of the interesting ideas that he presented were that the trusts of homes would not gravitate towards contract law nor towards unjust enrichment but rather it would remain a question for trusts law. He argued that it was not a good idea for the court to make 'such a change' before the long expected Law Commission proposals ${ }^{250}$. In his opinion fusion of proprietary estoppel and

243 Stack v Dowden [2007] UKHL 17 para 69.

244 D. Sevitt, \& J. Freeman, "Stack v Dowden: determining property rights on separation of unmarried cohabitants" P.C.B. (2007): 366-373.

245 Stack v Dowden [2007] UKHL 17.

${ }^{246}$ T. Etherton, "Constructive trusts and proprietary estoppel: the search for clarity and principle" Conv. (2009): 104-126 at 107-108.

247 [2004] EWCA Civ 546.

248 Oxley v Hiscock [2004] EWCA Civ 546 at para 69.

249 T. Etherton, "Constructive trusts and proprietary estoppel: the search for clarity and principle" Conv. (2009): 104-126 at 107-108.

250 Cohabitation: The Financial Consequences of Relationships Breakdown, Law Com No. 307 (London: HMSO, 2007). The report looks at people living together as an 
constructive trust was incorrect while the doctrine of resulting trust was of limited usefulness in this context. He accepted the fact that the law has moved on from the strict test established in Rosset ${ }^{251}$ towards unconscionability approach and consideration of the whole course of dealing between the parties ${ }^{252}$. Swadling in his article argued that "it is certainly a pity that the issue of resulting trusts was not more fully ventilated" by their Lordships ${ }^{253}$.

Lord Neuberger in his dissenting judgment held that the case should be decided on the resulting trust principles however this notion was not supported by the majority in the House of Lords. He suggested that courts should begin with resulting trust analysis based on parties' financial contributions and then proceed with constructive trust principles to reflect parties' common intention that might have changed while they were occupying the property. Hence his idea was similar to the judgment in Huntingford $v$ Hobbs; however, he failed to explain the basis on which constructive trust principles would operate ${ }^{254}$.

Although their Lordships in Stack ${ }^{255}$ attempted to clarify the law in relation to family home trusts, their overly general judgments indicated that too much uncertainty remained ${ }^{256}$. Rimer LJ in the Court of Appeal, in Jones $v$ Kernott" concluded that, "I am not sure, with respect, what is to be made of the emphasis by Baroness Hale and Lord Walker that Stack was an exceptional case ${ }^{\text {"258 }}$ while Gardner in his article noted that "It is hard to read the decision of the House of Lords in Stack without concluding that it has

unmarried couple and contains recommendations regarding the law as it affects cohabitants' property and finances when their relationships end.

251 Lloyds Bank v Rosset [1991] 1 A.C. 107.

252 A. Hudson, Equity and Trusts, 7th ed., Routledge, 2012, p. 769-770.

253 W. Swadling, "Case Comment. The common intention constructive trust in the House of Lords: an opportunity missed” L.Q.R. (2007): 511-518 at 518.

254 A. Hudson, Equity and Trusts, 7th ed., Routledge, 2012, p. 774.

255 Stack v Dowden [2007] UKHL 17.

256 A. Hudson, Equity and Trusts, 7th ed., Routledge, 2012, p. 776.

257 [2010] EWCA Civ 578.

258 Rimer LJ quoted in the article of J. Roche, "Kernott, Stack, and Oxley made simple: a practitioner's view” Conv. (2011): 123-139 at 128. 
certain difficulties" 259 Therefore, even though the decision of the House of Lords was 'ground-breaking' it "caused more confusion rather than the conceptual revolution it hoped to precipitate ${ }^{2660}$.

\section{James v Thomas [2007]}

In this case, the Court of Appeal affirmed the strength of the Stack ${ }^{261}$ presumption in relation to sole legal ownership ${ }^{262}$. In 1989, Miss James and $\mathrm{Mr}$ Thomas formed a relationship and Miss James moved into 'The Cottage' which was registered in Mr Thomas's sole name. At the outset of the relationship, Miss James gave Mr Thomas $£ 5000$ to pay a tax bill and soon after moving in, she began working in Mr Thomas's business which he ran from The Cottage; she received no remuneration for her work. She also helped him with the renovation works on the property. When they separated, Miss James claimed an equal share in the property. Her claim was dismissed and the Court of Appeal upheld that judgment.

Sir John Chadwick with whom the other judges agreed said that, "a constructive trust can arise some years after the property has been acquired by...one party who (at the time of acquisition) was .... the sole beneficial owner...but...in the absence of an express post-acquisition agreement, a court will be slow to infer from conduct alone that parties intended to vary existing beneficial interest established at the time of acquisition "263. He suggested that the claimant might rebut the presumption of the sole ownership and the constructive trust could arise after the acquisition of the property; thus he followed Gissing ${ }^{264}$. However, he noted that without an express agreement, the court would be careful with inferring the parties' common intention as regards their shares based solely on their conduct ${ }^{265}$.

259 S. Gardner \& K.M. Davidson, “The future of Stack v Dowden” L.Q.R. (2011): $13-19$ at 13 .

260 A. Hudson, Equity and Trusts, 7th ed., Routledge, 2012, p. 42.

261 Stack v Dowden [2007] UKHL 17.

262 A. Dyson, "All's fair in love and war: an analysis of the common intention constructive trust” C.S.L.R. (2008): 149-166 at 154.

263 James v Thomas [2007] EWCA Civ 1212 para 24.

264 Gissing v Gissing [1971] AC 886 at 901.

265 T. Etherton, "Constructive trusts and proprietary estoppel: the search for clarity and principle” Conv. (2009): 104-126 at 114. 
Sir John Chadwick held that contributions made by Miss James to the business and the property, were not sufficient for the court to infer common intention because the facts were 'explicable on other grounds' ${ }^{266}$. Dyson in his article noted that this narrow approach of inferred common intention came from the decision in Rosset ${ }^{267}$. He mentioned that in this case "the stringent adherence to the presumption... may have given rise to some unfairness... [and] the Court of Appeal may have gone too far in their application of the Stack presumption ${ }^{\text {268 }}$.

\section{Fowler v Barron [2008]}

In Fowler $v$ Barron ${ }^{269}$ the Court of Appeal had the first opportunity to challenge the age-old maxim that actions speak louder than words ${ }^{270}$. In 1987 Miss Fowler and Mr Barron decided to purchase a property. The house was transferred into their joint names without express agreement as to their respective equitable shares. The property cost $£ 64,500$ of which $£ 35,000$ was paid by way of mortgage taken in the parties' joint names. $\mathrm{Mr}$ Barron paid most of the mortgage instalments and all fixed costs associated with the property such as utility bills. Miss Fowler spent most of her income on children. The parties had drawn up mutual wills. Mr Barron and Miss Fowler were in an unmarried relationship until 2005 when they separated. The question arose as to their respective equitable shares in the house. The High Court held that Mr Barron was the sole beneficial owner based on a presumption of a resulting trust. Miss Fowler appealed on the basis that the judge should consider common intention constructive trust rather than resulting trust principles to determine whether she had a beneficial interest in the property. Mr Barron argued that he put the property in joint names because he intended Miss Fowler to have an interest in the

266 A. Dyson, "All's fair in love and war: an analysis of the common intention constructive trust” C.S.L.R. (2008): 149-166 at 154.

267 Lloyds Bank v Rosset [1991] 1 A.C. 107.

268 A. Dyson, "All's fair in love and war: an analysis of the common intention constructive trust” C.S.L.R. (2008): 149-166 at 155.

269 [2008] EWCA Civ 337.

270 N. Piska, "Two recent reflections on the resulting trust" Conv. (2008): 441-463 at 451 . 
property if he died before her ${ }^{271}$. Arden LJ with whom the other judges agreed held that instead of looking at parties' financial contributions, the court should answer the question whether Mr Barron had discharged the burden that it was not parties' common intention to have equal shares in the property. Arden LJ held that Mr Barron failed to rebut the presumption of joint tenancy and the fact that he contributed most of the purchase price was not sufficient ${ }^{272}$.

Piska in his article said that, the decision in Fowler should be welcomed for providing clarification of a number of issues arising from Stack ${ }^{273}$. Despite the fact that their Lordship in Stack $^{274}$ found that parties' shares were intended to be held in accordance with their financial contributions, Fowler ${ }^{275}$ confirmed that "the parties could be equal owners even though their financial contributions to the purchase cost had been unequal ${ }^{276}$. The claimant may be entitled to a half-share in the property based solely on the legal title placed in joint names, despite the lack of financial contributions made towards acquisition ${ }^{277}$. Hence, "the courts...seem to take the view that in domestic cases the resulting trust is old news" ${ }^{278}$.

Fowler $^{279}$ confirmed that in taking 'holistic approach' to determining parties' shared intention the court "will take into account... but is not limited to, the financial contributions... towards the acquisition of the property or repayment of any loan raised for such a purpose"280. Thus courts may consider other factors than direct financial contributions towards acquisition when

271 Fowler v Barron [2008] EWCA Civ 377.

272 N. Piska, "Two recent reflections on the resulting trust" Conv. (2008): 441-463 at $453-454$.

273 Ibid, at 455.

274 Stack v Dowden [2007] UKHL 17.

275 Fowler v Barron [2008] EWCA Civ 377.

276 Ibid, at para 18.

277 M. Pawlowski \& J. Brown, "Joint purchasers and the presumption of joint beneficial ownership - a matter of informed choice?” Tru. L.I. (2013): 3-17 at 5.

${ }_{278}$ N. Piska, "Two recent reflections on the resulting trust" Conv. (2008): 441-463 at 461 .

279 Fowler v Barron [2008] EWCA Civ 377.

280 Ibid, at para 24. 
determining parties' common intention, for instance, optional expenditure such as holidays, gifts or school trips ${ }^{281}$.

\section{Conclusion}

George in his article concluded that although Stack ${ }^{282}$ recognised that the presumption is that the beneficial ownership mirrors legal ownership and explained how the beneficial interest should be quantified in cases where that presumption was rebutted, it did not answer three main questions. First, when should the court depart from the starting point that beneficial ownership reflects legal title? Second, is there a difference between sole-name and joint-name cases besides the fact that starting points are different? Third, are the judges allowed to impute parties' common intention $^{283}$ ? Therefore, the law in relation to family home trusts after Stack ${ }^{284}$ was in many respects no clearer than it had been before that case was decided $^{285}$. After Stack ${ }^{286}$ the courts continued to select doctrines and ideas from any or all of the cases decided from Pettitt v Pettitt ${ }^{287}$ to Stack $^{288}$ and the doctrine of precedent had been undermined ${ }^{289}$.

In 2007 the Law Commission published a report $^{290}$ followed by a 2006 consultation paper ${ }^{291}$ to which a wide range of individuals and organisations responded. It proposed a new statutory scheme to deal with the property rights of cohabitants on relationship breakdown. Huges \& Davis \& Jacklin noted in their article that, "the essence of the proposals [was]

281 N. Piska, "Two recent reflections on the resulting trust" Conv. (2008): 441-463 at $454-456$.

282 Stack v Dowden [2007] UKHL 17.

${ }^{283}$ R.H. George, "Case comment: Cohabitants' property rights: when is fair fair?" C.L.J. (2012): 39-42 at 39-40.

284 Stack v Dowden [2007] UKHL 17.

285 M. Harding, "Defending Stack v Dowden” Conv. (2009): 309-325 at 309.

286 Stack v Dowden [2007] UKHL 17.

287 [1970] A.C. 777.

288 Stack v Dowden [2007] UKHL 17.

289 A. Hudson, Equity and Trusts, 7th ed., Routledge, 2012, p. 778-779.

290 Cohabitation: The Financial Consequences of Relationships Breakdown, Law Com No. 307 (London: HMSO, 2007).

291 Cohabitation: The Financial Consequences of Relationship Breakdown, Law Commission Consultation Paper No 179, 2006. 
that the law should address particular economic consequences of varying contributions made by parties to a cohabitation relationship on its breakdown ${ }^{292}$. Nonetheless, the legislature did not implement Law Commission's proposals for legislative reform to deal with this matter; hence the legal uncertainty remained ${ }^{293}$. According to Doyle and Brown, one of the reasons why Parliament has been denied any serious opportunity of reforming this area of law is the fact that, "none of the major political parties wish to be perceived as devaluing the formalised institutions of marriage or civil partnership ${ }^{294}$.

\section{THE DECISION IN JONES V KERNOTT}

\section{Jones v Kernott [2011]}

The decision of the Supreme Court in this case was highly anticipated by both practitioners and academics alike and seen as an opportunity to answer certain questions left post-Stack. ${ }^{295}$ This case concerned an unmarried couple who bought a house in joint names for $£ 30,000$ with a contribution of $£ 6,000$ from Miss Jones; the remainder was financed by way of endowment mortgage. Mr Kernott contributed $£ 100$ per week to household expenses, with Miss Jones paying for everything else out of joint resources. The couple had two children. In 1993 the couple separated and Miss Jones took over the responsibility to pay the expenses associated with the disputed property while Mr Kernott cashed in a life insurance policy and purchased a new house. He made very little contribution to the maintenance of his two children. In 2006, Mr Kernott claimed an equitable interest in the disputed property. The judge at first instance held that the

${ }^{292}$ D. Huges, \& M. Davis \& L. Jacklin, "Come live with me and be my love' - a consideration of the 2007 Law Commission proposals on cohabitation breakdown" Conv. (2008): $197-225$ at 197.

293 J. Mee, "Case Comment: Jones v Kernott: inferring and imputing in Essex" Conv. (2012): $167-180$ at 178 .

${ }^{294}$ A. Doyle \& J. Brown, "Case comment. Jones v Kernott: which road to Rome?" Tru. L.I. (2012): 96-105 at 104-105.

295 A. Doyle \& J. Brown, "Case comment. Jones v Kernott: which road to Rome?" Tru. L.I. (2012): 96-105 at 96. 
equitable interest in the property should be divided roughly in ratio 90:10 in favour of Miss Jones and this was later confirmed by the High Court. The Court of Appeal disagreed and held that this was a joint tenancy. The Supreme Court reversed the judgment from the Court of Appeal and restored the decision of the lower courts.

Lord Walker and Lady Hale delivered the leading judgment. They concluded that where there is no express trust declared, the courts would look for parties' common intention as to their equitable ownership in the property. The presumption would be that the beneficial interest mirrors legal ownership. However, it might be rebutted on the evidence to the contrary either before or after the property was purchased. If the common intention was not apparent from the facts of the case, the court would seek to objectively infer it from the evidence; if the evidence was not conclusive, the court would seek to achieve the fairness between the parties ${ }^{296}$. This methodology clearly precludes using resulting trusts in this area of law $^{297}$. Lord Walker and Lady Hale confirmed that constructive trusts of the family home can be 'ambulatory' in nature as parties' intentions could change over time ${ }^{298}$.

Lord Walker and Lady Hale with whose reasons Lord Collins agreed said that it was possible to infer from Miss Jones and Mr Kernott's behaviour that they had formed a common intention after their separation that the beneficial interests would differ from the legal title. Lord Wilson and Lord Kerr took the same view ${ }^{299}$. As regards imputation, it appears that Lord Walker and Lady Hale found it not permissible to impute common intention when deciding whether the beneficial interests were intended to differ from the legal title and Lord Collins supported this notion ${ }^{300}$. Even Lord Wilson noted that imputation of such common intention would "merit careful thought'301.

296 Jones v Kernott [2011] UKSC 53 at para $51-52$.

297 A. Doyle \& J. Brown, "Case comment. Jones v Kernott: which road to Rome?" Tru. L.I. (2012): 96-105 at 101.

298 Ibid, at 99.

299 J. Mee, "Case Comment: Jones v Kernott: inferring and imputing in Essex" Conv.

(2012): $167-180$ at 169 .

300 Ibid, at 173 .

301 Jones v Kernott [2011] UKSC 53 at para 84. 
Lord Walker and Lady Hale, with whom Lord Collins agreed, suggested that it was possible to infer a common intention as to what the parties' respective beneficial interests would be. However, Lord Wilson and Lord Kerr argued that it was not possible to infer that parties had an actual common intention in relation to the quantum of their respective shares and they preferred to reach the equivalent result by means of imputation ${ }^{302}$. Lord Walker and Lady Hale would also be willing to reach this result by means of imputation had they believed that no common intention as to shares could be inferred ${ }^{303}$.

Although all the judges appeared to accept the conceptual difference between inferring and imputing ${ }^{304}$, they had different opinions as to the practical significance of the distinction. Lord Walker, Lady Hale and Lord Collins suggested that the difference in practice between imputation and inference is not so great while Lord Kerr disagreed with their conclusion and Lord Wilson noted that such generalisation goes too far ${ }^{305}$.

\section{Analysis}

George argued that post Stack ${ }^{306}$ three questions remained (as mentioned above). First, in what circumstances should the court depart from the starting point that beneficial ownership reflects legal title? Second, are the sole-name and joint-name cases different besides the fact that starting points are different? Third, are the judges allowed to impute parties' common intention? According to George, Jones ${ }^{307}$ had the potential to answer all of them. As regards third question, he noted that the Supreme Court was clear that the court could impute parties' common intention at the

302 J. Mee, "Case Comment: Jones v Kernott: inferring and imputing in Essex" Conv. (2012): $167-180$ at $169-170$.

303 Ibid, at 170 .

304 Jones v Kernott [2011] UKSC 53 at para 26-36 per Lord Walker and Lady Hale, at para 64-65 per Lord Collins, at para 73-75 per Lord Kerr, at para 79-84 per Lord Wilson. This conclusion was reached by J. Mee, "Case Comment: Jones v Kernott: inferring and imputing in Essex" Conv. (2012): 167-180 at 175.

305 J. Mee, "Case Comment: Jones v Kernott: inferring and imputing in Essex" Conv. (2012): $167-180$ at 175 .

306 Stack v Dowden [2007] UKHL 17.

307 Jones v Kernott [2011] UKSC 53. 
quantification stage. As regards the second question, the court mentioned in obiter dicta that although the starting points in the sole-name and jointname cases are different, this "does not imply any difference in the analytical process" 308 . However as regards first question, George said that it remained unresolved because Jones ${ }^{309}$ failed to specify what evidence counts in rebutting the presumption that beneficial ownership mirrors legal ownership. George concluded that many difficulties arising from Stack ${ }^{310}$ are likely to remain because even though Jones ${ }^{311}$ clarified how the quantification process works, it failed to provide an explanation as to when it is needed ${ }^{312}$.

According to Doyle and Brown, Jones ${ }^{313}$ provided a clear justification as to why resulting trusts do not play a role with family homes and clarified "the structure for finding a constructive trust, at least for cases where both parties have legal ownership ${ }^{\text {'14 }}$. They mentioned that the minority was right when saying that there ought to be a clear demarcation between imputation and inference in practice as well as in theory. Although the outcome under either process can lead to the same result, this is not always the case. They argued that the lack of explicit reference to holistic factors which would be used for finding a constructive trust and for quantifying the equitable interest, was a "missed opportunity to bring a further clarification to the law in this respect"315. In their opinion, it was unclear how the concept of 'fairness' should be used to quantify an imputed intention once it is found. Doyle and Brown concluded that Jones ${ }^{316}$ failed to clarify all the issues from Stack and created new areas of uncertainty ${ }^{317}$.

308 R.H. George, "Case comment: Cohabitants' property rights: when is fair fair?" C.L.J. (2012): 39-42 at 41.

309 Jones v Kernott [2011] UKSC 53.

310 Stack v Dowden [2007] UKHL 17.

311 Jones v Kernott [2011] UKSC 53.

312 R.H. George, "Case comment: Cohabitants' property rights: when is fair fair?" C.L.J. (2012): 39-42.

313 Jones v Kernott [2011] UKSC 53.

314 A. Doyle \& J. Brown, "Case comment. Jones v Kernott: which road to Rome?" Tru. L.I. (2012): 96-105 at 103.

315 Ibid, at 100 .

316 Jones v Kernott [2011] UKSC 53.

317 A. Doyle \& J. Brown, "Case comment. Jones v Kernott: which road to Rome?" Tru. L.I. (2012): 96-105. 
Dixon said that Jones ${ }^{318}$ makes it clear that the parties' common intention can change over time and thus "the equitable interests of the parties can vary over time both in size and type $e^{319} \mathrm{He}$ stated that one of the issues that arose in Jones ${ }^{320}$ was the lack of explanation as to how the parties' tenancy in common in shares of 9 to 1 resulted from the joint tenancy; there was no mention of severance in the judgment. He underlined that post Jones ${ }^{321}$ there are many questions left unanswered. For instance, how is the common intention proven? Is the resulting trust of any use in residential cases? What is the role of detrimental reliance in similar cases? He suggested that the reason why Jones ${ }^{322}$ raised so many property law questions was because the case was not really based on property law ${ }^{323}$. It was rather family law or "an exercise of the court's inherent equitable jurisdiction"324.

Mee in his article reached a similar conclusion to Doyle \& Brown ${ }^{325}$. He said that although Jones ${ }^{326}$ did clarify a number of aspects of Stack ${ }^{327}$, it raised a new set of concerns. He argued that the major contribution was made with regards to the appropriate nature of the process of inference. However he noted that, "unfortunately, on this point it seems clear that the minority took the preferable position"328. Lord Kerr and Lord Wilson as opposed to the majority said that there is a significant difference between inference and imputation in practice. As regards imputation, Mee stated that their Lordship's discussion on that matter confused the common intention doctrine rather than brought any greater theoretical coherence

318 Jones v Kernott [2011] UKSC 53.

319 M. Dixon, "Editorial. Editor's notebook: the still not ended, never-ending story" Conv. (2012): 83-86 at 83 .

320 Jones v Kernott [2011] UKSC 53.

321 Ibid.

322 Ibid.

323 M. Dixon, "Editorial. Editor's notebook: the still not ended, never-ending story" Conv. (2012): 83-86.

324 Ibid, at 86.

325 A. Doyle \& J. Brown, "Case comment. Jones v Kernott: which road to Rome?" Tru. L.I. (2012): 96-105.

326 Jones v Kernott [2011] UKSC 53.

327 Stack v Dowden [2007] UKHL 17.

328 J. Mee, "Case Comment: Jones v Kernott: inferring and imputing in Essex" Conv. (2012): $167-180$ at 179 . 
to $\mathrm{it}^{329}$. Also, Mee underlined that since Jones was a joint names case, the "position in relation to sole name cases remains to be tested in detail"330.

Yip contended that although Jones ${ }^{331}$ clarified the principles laid down in Stack"332, it "would] certainly not be the last word on the rules applying to unmarried cohabitants' family home. ${ }^{333}$ He noted that Jones ${ }^{334}$ provided courts with a set of basic rules that apply to trusts in relation to unmarried cohabiting couples. However he repeated Mee in saying that clarification with regards to sole name cases is required ${ }^{335}$.

\section{CONCLUSION}

The issue of rights in the home is an important socio-economic phenomenon ${ }^{336}$. The statistics on unmarried couples show that about one in six people are in a cohabiting relationship while the number of married couples in England and Wales is decreasing ${ }^{337}$. Douglas et al estimated that by 2031 the total number of couples cohabiting outside marriage will rise to 3.8 million $^{338}$.

This dissertation has set out to consider whether the decision of the Supreme Court in Jones $v$ Kernott ${ }^{33}$ clarified the law in relation to trusts

329 Ibid, at 175 .

330 Ibid, at 180 .

331 Jones v Kernott [2011] UKSC 53.

332 Stack v Dowden [2007] UKHL 17.

333 M. Yip, "Case comment. The rules applying to unmarried cohabitants' family home: Jones v Kernott” Conv. (2012): 159-167 at 167.

334 Jones v Kernott [2011] UKSC 53.

335 M. Yip, "Case comment. The rules applying to unmarried cohabitants' family home: Jones v Kernott” Conv. (2012): 159-167 at 159-162.

${ }_{336}$ A. Hudson, Equity and Trusts, 7th ed., Routledge, 2012, p. 793.

337 A. Doyle \& J. Brown, "Case comment. Jones v Kernott: which road to Rome?" Tru. L.I. (2012): 96-105 at 96.

${ }^{338}$ G. Douglas \& J. Pearce \& H. Woodward, "Cohabitation and conveyancing practice: problems and solutions” Conv. (2008): 365-381at 367.

339 Jones v Kernott [2011] UKSC 53. 
of the family home. In order to answer the research question, it has been necessary to consider the development of the law since the early cases of Pettitt $v$ Pettitit ${ }^{30}$ and Gissing $v$ Gissing $g^{341}$.

It is clear that even though the case of Jones $v$ Kernott $t^{342}$ clarified a number of issues from Stack $v$ Dowden $n^{343}$, there remain areas of uncertainty in the law of trusts of the family home. It is submitted that until Parliament undertakes the task of implementing legislative reform that would resolve cohabitation issues, "the courts will struggle to resolve adequately the property disputes that can arise in the event of relationship breakdown ${ }^{334}$.

\section{REFERENCES:}

\section{TEXTBOOKS}

Clements Richard, Abass Ademola, Equity and Trusts: Text, Cases and Materials, $2^{\text {nd }}$ ed., Oxford University Press, 2011.

Gray Kevin, Gray Susan Francis, Elements of Land Law, Oxford University Press, 2005.

Hudson Alastair, Equity and Trusts, $7^{\text {th }}$ ed., Routledge, 2012.

Panesar Sukhninder (2012) 'Exploring Equity and Trusts', $2^{\text {nd }}$ ed., Pearson Education Ltd.

Virgo Graham (2012) 'The Principles of Equity \& Trusts' 1st ed., Oxford University Press.

\section{JOURNAL ARTICLES}

Dixon Martin, “Case Comment: A case too far?” Conv. (1997): 66-73.

340 [1970] A.C. 777.

341 [1971] AC 886.

342 Jones v Kernott [2011] UKSC 53.

343 Stack v Dowden [2007] UKHL 17.

344 A. Doyle \& J. Brown, "Case comment. Jones v Kernott: which road to Rome?" Tru. L.I. (2012): 96-105 at 105. 
Dixon Martin, "Case Comment: Resulting and constructive trusts of land: the mist descends and rises" Conv. (2005): 79-88.

Dixon Martin, "Editorial. Editor's notebook: the still not ended, never-ending story” Conv. (2012): 83-86.

Douglas Gillian \& Pearce Julia \& Woodward Hilary, "Cohabitation and conveyancing practice: problems and solutions" Conv. (2008): 365-381.

Doyle Adam \& Brown James, "Case comment. Jones v Kernott: which road to Rome?” Tru. L.I. (2012): 96-105.

Dyson Andrew, "All's fair in love and war: an analysis of the common intention constructive trust" C.S.L.R. (2008): 149-166.

Etherton Terence, "Constructive trusts: a new model for equity and unjust enrichment” C.L.J. (2008): 265-287.

Etherton Terence, "Constructive trusts and proprietary estoppel: the search for clarity and principle" Conv. (2009): 104-126.

Gardner Simon, "Case Comment: Quantum in Gissing v Gissing constructive trusts" L.Q.R. (2004): 541-548.

Gardner Simon, "Case Comment: Fin de siècle chez Gissing v Gissing" L.Q.R (1996): 378-383.

Gardner Simon \& Davidson Katharine, "The future of Stack v Dowden" L.Q.R. (2011): 13-19.

George Robert, "Case comment: Cohabitants' property rights: when is fair fair?" C.L.J. (2012): 39-42.

Harding Matthew, “Defending Stack v Dowden” Conv. (2009): 309-325.

Hughes David \& Davis Martin \& Jacklin Louise, "Come live with me and be my love' - a consideration of the 2007 Law Commission proposals on cohabitation breakdown" Conv. (2008): 197-225.

Mee John, "Case Comment: Jones v Kernott: inferring and imputing in Essex" Conv. (2012): 167-180.

Norman Helen, "Case Comment: Resulting trusts - determining beneficial entitlement" Conv. (1992): 347-354.

Pawlowski Mark \& Brown James, "Joint purchasers and the presumption of joint beneficial ownership - a matter of informed choice?" Tru. L.I. (2013): 3-17.

Piska Nick, "Two recent reflections on the resulting trust" Conv. (2008): 441-463

Roche Juanita, "Kernott, Stack, and Oxley made simple: a practitioner's view" Conv. (2011): 123-139.

Rotherham Craig, "The property rights of unmarried cohabitees: the case for reform" Conv. (2004): 268-292. 
Sevitt Deborah, \& Freeman James, "Stack v Dowden: determining property rights on separation of unmarried cohabitants" P.C.B. (2007): 366-373.

Smithdale James, "Inference, imputation, or both? Confusion persists over beneficial interests in the family home" C.S.L.R. (2011): 74-88.

Swadling William, "Case Comment. The common intention constructive trust in the House of Lords: an opportunity missed" L.Q.R. (2007): 511-518.

Thomson Mark, „Case Comment: Constructive trusts, estoppel and the family home" Conv. (2004): 496-507.

Yip Man, "Case comment. The rules applying to unmarried cohabitants' family home: Jones v Kernott” Conv. (2012): 159-167.

\section{OTHER SOURCES}

\section{Law Commission Report:}

Cohabitation: The Financial Consequences of Relationships Breakdown, Law Com No. 307 (London: HMSO, 2007),

\section{Law Commission Consultation Paper:}

Cohabitation: The Financial Consequences of Relationship Breakdown, Law Commission Consultation Paper No 179, 2006

\section{An article from 'Family Law Week':}

Barnes Luke, "Defining Detriment”, Family Law Week, (2009) on http://www. familylawweek.co.uk/site.aspx?i=ed34330 last accessed on 20.09.2016 
